CRYSTALLOGRAPHIC COMMUNICATIONS
Received 10 January 2020

Accepted 17 February 2020

Edited by W. T. A. Harrison, University of Aberdeen, Scotland

Keywords: crystal structure; Schiff bases; nonlinear optical properties; disorder; hydrogen bonding; Hirshfeld surface analysis.

CCDC reference: 941508

Supporting information: this article has supporting information at journals.iucr.org/e

\section{Whole-molecule disorder of the Schiff base compound 4-chloro-N-(4-nitrobenzylidene)aniline: crystal structure and Hirshfeld surface analysis}

\author{
Sundararaman Leela, ${ }^{\mathrm{a}, \mathrm{b} *}$ Ashokkumar Subashini, ${ }^{\mathrm{b}, \mathrm{c}}$ Philip Reji, ${ }^{\mathrm{d}}$ Kandasami \\ Ramamurthi $^{\mathrm{e}}$ and Helen Stoeckli-Evans ${ }^{\mathrm{f}}{ }$
}

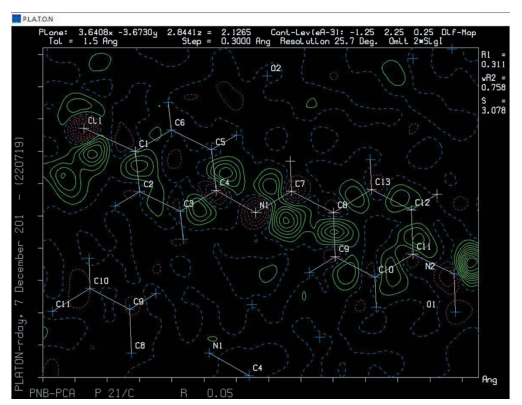

OPEN ӘACCESS a Department of Physics, Ethiraj College for Women, Chennai - 600008 , Tamilnadu, India, ${ }^{\mathbf{b}}$ Crystal Growth and Thin Film Laboratory, School of Physics, Bharathidasan University, Tiruchirappalli - 620 024, India, ${ }^{\mathbf{C}} \mathrm{PG}$ and Research Department of Physics, Srimad Andavan Arts and Science College, Tiruchirappalli - 620 005, India, $\mathbf{d}$ Light and Matter Physics Group, Raman Research Institute, C. V. Raman Avenue, Sadashivanaga, Bangalore - 560 080, India, ${ }^{\mathbf{e}}$ Department of Bio-Medical Engineering, Aarupadai Veedu Institute of Technology, Vinayaga Mission's Research Foundation, Vinayaga Nagar, Paiyanoor, 603 104, Tamil Nadu, India, and 'Institute of Physics, University of Neuchâtel, rue Emile-Argand 11, CH-2000 Neuchâtel, Switzerland. *Correspondence e-mail: leelabeena@gmail.com, helen.stoeckli-evans@unine.ch

In the crystal of the title Schiff base compound, $\mathrm{C}_{13} \mathrm{H}_{9} \mathrm{ClN}_{2} \mathrm{O}_{2}$, [CNBA; systematic name: $(E)-N$-(4-chlorophenyl)-1-(4-nitrophenyl)methanimine], the CNBA molecule shows whole-molecule disorder (occupancy ratio 0.65:0.35), with the disorder components related by a twofold rotation about the shorter axis of the molecule. The aromatic rings are inclined to each other by $39.3(5)^{\circ}$ in the major component and by $35.7(9)^{\circ}$ in the minor component. In the crystal, $\mathrm{C}-\mathrm{H}$. . O hydrogen bonds predominate in linking the major components, while weak $\mathrm{C}-\mathrm{H} \cdots \mathrm{Cl}$ interactions predominate in linking the minor components. The result is the formation of corrugated layers lying parallel to the $a c$ plane. The crystal packing was analysed using Hirshfeld surface analysis and compared with related structures.

\section{Chemical context}

A number of benzylideneaniline derivatives crystallize in noncentrosymmetric space groups and are therefore of interest for their non-linear optical properties (Bar \& Bernstein, 1977; Batra et al., 2004). In 1970, Bürgi \& Dunitz (1970) analysed a number of $N$-benzylanilines and found that they were twisted about the $\mathrm{N}=\mathrm{C}$ bond unlike trans-stilbenes (see for example: Behrnd et al., 2010; De Borger et al., 2005) or trans-azobenzenes (see for example: Huang et al., 2002; Bushuyev et al., 2016), which are almost planar.

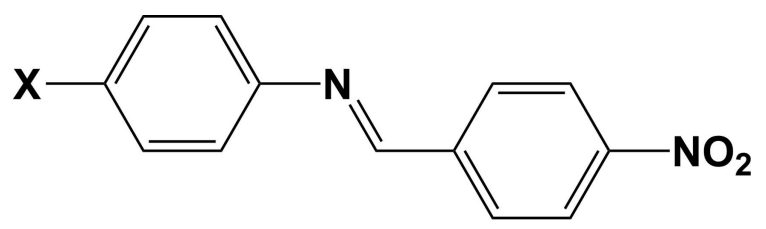

$$
\begin{array}{ll}
\mathrm{X}=\mathrm{H} & \text { (HNBA) } \\
\mathrm{X}=\mathrm{F} & \text { (FNBA) } \\
\hline \mathrm{X}=\mathrm{Cl} & \text { (CNBA) } \\
\hline \mathrm{X}=\mathrm{Br} & \text { (BNBA) } \\
\mathrm{X}=\mathrm{CH}_{3} & \text { (MNBA) } \\
\mathrm{X}=\mathrm{CH}_{3} \mathrm{O} & \text { (MONBA) } \\
\mathrm{X}=\mathrm{OH} & \text { (HONBA) }
\end{array}
$$


Benzylideneaniline derivatives are known to exhibit disorder and Bernstein and collaborators (Bar \& Bernstein, 1983; Kluge et al., 2003) have defined the different types of orientational disorder of these compounds, where the molecules may be oriented in different ways but in the two or more dispositions each atom is essentially superimposed on another at any one crystallographic site. Static disorder around the $\mathrm{C}=\mathrm{N}$ bond is also responsible for the apparent shortening of the $\mathrm{C}=\mathrm{N}$ bond at room temperature (Bar \& Bernstein, 1984). This phenomenon has also been studied by Harada et al. (2004a), who, by means of a variable temperature study, concluded that the shortening depends on temperature and is due to a torsional vibration of the $\mathrm{C}-$ phenyl and $\mathrm{N}-$ phenyl bonds in the crystals.

The crystal structures of a number of disordered benzylideneaniline compounds have been reported on and various forms of the disorder have been analysed (Bar \& Bernstein, 1977, 1984; Harada et al., 2004a,b). The disorder appears to fall into three categories (Fig. 1): $D 1$ - twofold rotation about the longer axis of the molecule, $D 2$ - the molecule is located about a crystallographic center of symmetry, and D3 - twofold rotation about the shorter axis of the molecule.

Type $D 1$ disorder has been observed for one of the two independent molecules in the crystal of $N$-(4-nitrobenzylidene)aniline at 300 and $200 \mathrm{~K}$, but the disorder is not present at $90 \mathrm{~K}$ (Harada et al., 2004b). Orientational disorder about a center of symmetry (type $D 2)$ was found in $N$-( $p$-chlorobenzylidene)-p-chloroaniline (Bar \& Bernstein, 1982; Bernstein \& Schmidt, 1972). Type D3 disorder has been observed for $N$-benzylideneaniline (Bernstein \& Izak, 1976; Harada et al., 2004a) and for 4-methyl-4'-methoxybenzylideneaniline (Harada et al., 2004a).

Three forms of $p$-methyl- $N$-( $p$-methylbenzylidene)aniline (Bernstein, Bar \& Christensen, 1976; Bar \& Bernstein, 1982; Bar \& Bernstein, 1977) have been shown to exist: Form I (Bar $\&$ Bernstein, 1982), crystallizes in space group $P 2_{1} / c$ and the $\mathrm{C}=\mathrm{N}$ bond of the molecule is located about a center of symmetry, hence the molecule has type $D 2$ disorder; form II (Bar \& Bernstein, 1977) crystallizes in space group $P 2_{1}$ and the molecule is not disordered; form III (Bar \& Bernstein, 1977; Harada et al., 2004b), has a fourfold disorder with the mol-
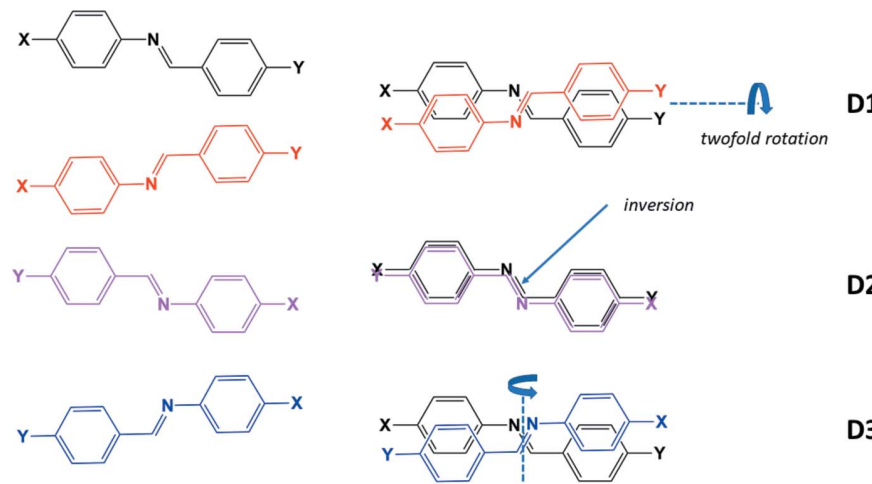

D2

Figure 1

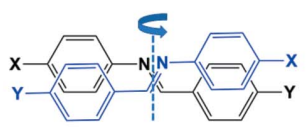

D3

Disorder types in benzylideneanilines.

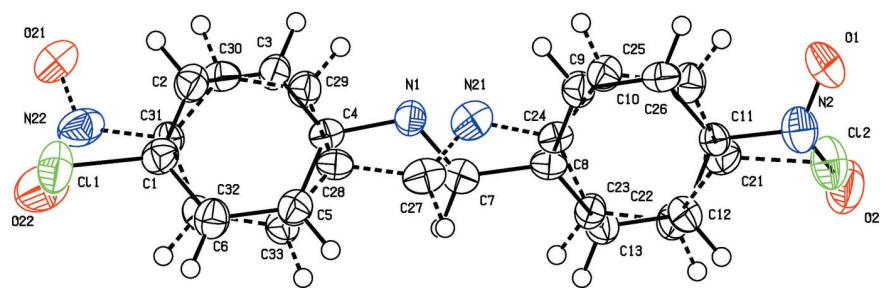

Figure 2

Molecular structure of CNBA, with atom labelling. The displacement ellipsoids are drawn at the $50 \%$ probability level. The major component is shown with solids bonds, while the minor component is shown with dashed bonds.

ecule being located about a center of symmetry and has a twofold rotation about the longer axis of the molecule $(D 1+$ D2).

In the past few years some benzylideneaniline compounds have been synthesized using $p$-nitrobenzaldehyde as one of the reactants; for example, 4-nitro-benzylideneaniline (HNBA; Harada et al., 2004b), 4-fluoro-4'-nitro-benzylideneaniline (FNBA; Subashini et al., 2013b), 4-bromo-4'-nitrobenzylideneaniline (BNBA; Subashini et al., 2013a) and 4hydroxy-4'-nitro-benzylideneaniline [systematic name: 4-[(E)(4-nitrobenzylidene)amino]phenol] (HONBA; Atioğlu et al., 2015).

To continue the series of 4-halogen species, we report herein on the crystal structure of 4-chloro-4'-nitro-benzylideneaniline (CNBA). It was previously synthesized by Batra et al. (2004), who found that the crystals they obtained showed good second harmonic generation (SHG) of 1.064 micron wavelength radiation. The crystal structure analysis carried out for CNBA in this work shows that it crystallizes in the centrosymmetric space group $P 2_{1} / c$, and that the molecule has positional disorder (type $D 3$ ), hence no SHG properties are expected for this particular sample. It is interesting to note that the structure of 4-bromo-4'-nitrobenzylideneaniline (BNBA) crystallizes in a non-centrosymmetric space group $(A 2)$, while the title compound and 4-fluoro-4'-nitrobenzylidene aniline (FNBA; Subashini et al., 2013b) both crystallize in space group $P 2_{1} / c$.

\section{Structural commentary}

The molecular structure of CNBA is shown in Fig. 2. It crystallizes in the centrosymmetric monoclinic space group $P 2_{1} / c$, and is disordered with a twofold rotation about the shorter axis of the molecule - type $D 3$. The twofold axis almost bisects the central $\mathrm{C}=\mathrm{N}$ bond, so that the two component molecules are superimposed head-to-tail, as shown clearly in a difference-Fourier map (Fig. 3). They have an occupancy ratio that, after initial refinement, was fixed at 0.649:0.351. As mentioned above, this type of disorder $(D 3)$ has been observed previously for related phases.

The configuration about the $\mathrm{C}=\mathrm{N}$ bond is $E$ in both components. The dihedral angle between the benzene rings of the major component CNBA_1 (C1-C6 and C8-C13) is $38.6(2)^{\circ}$, and that between rings $\mathrm{C} 21-\mathrm{C} 26$ and $\mathrm{C} 28-\mathrm{C} 33$ of the 


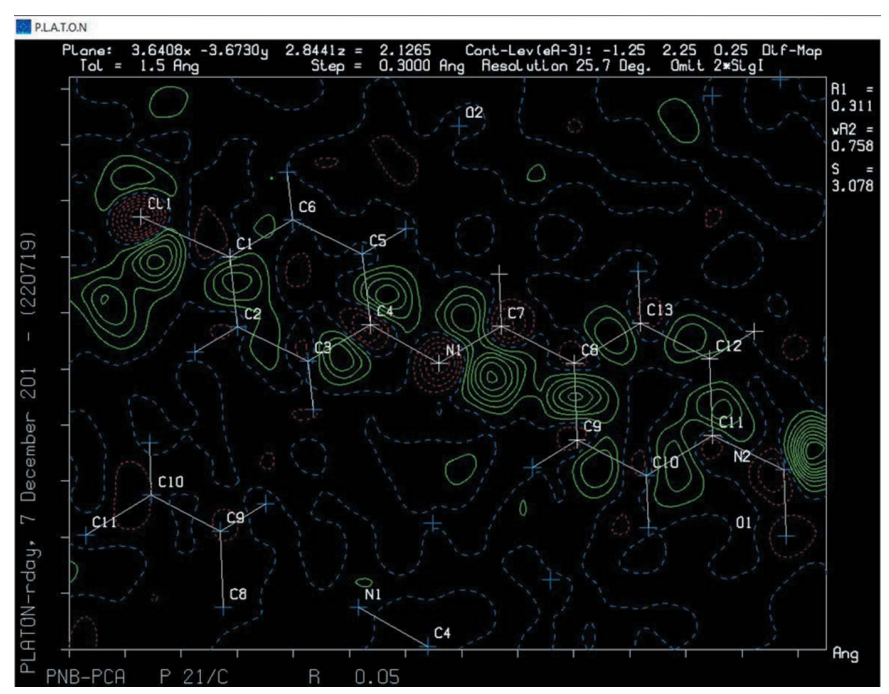

Figure 3

A difference electron-density map showing the density peaks related to the minor disordered component.

minor component (CNBA_2) is $36.5(4)^{\circ}$. In CNBA_1 the $\mathrm{N} 1=\mathrm{C} 7$ bond length is 1.291 (6) $\AA$, while for CNBA_2 the equivalent $\mathrm{N} 21=\mathrm{C} 27$ bond length is 1.234 (12) $\AA$. The $\mathrm{NO}_{2}$ group, N2/O1/O2, in CNBA_1 is inclined to benzene ring C8$\mathrm{C} 13$ by $2.2(7)^{\circ}$, and atom $\mathrm{Cl} 1$ is displaced by 0.016 (3) $\AA$ from benzene ring $\mathrm{C} 1-\mathrm{C} 6$. In component $\mathrm{CNBA}$-2, the $\mathrm{NO}_{2}$ group, $\mathrm{N} 22 / \mathrm{O} 21 / \mathrm{O} 22$, is inclined to benzene ring $\mathrm{C} 28-\mathrm{C} 33$ by $9.0(15)^{\circ}$, while atom $\mathrm{Cl} 2$ lies in the plane of the benzene ring C21-C26 [deviation 0.002 (5) Å].

\section{Supramolecular features}

A view along the $a$ axis of the crystal packing of CNBA is presented in Fig. 4, and details of the hydrogen bonding are given in Table 1. The crystal packing of the individual components, CBNA_1 and CBNA_2, are given in Fig. 5a and $5 b$, respectively. In Fig. $5 a$ it can be seen that the molecular

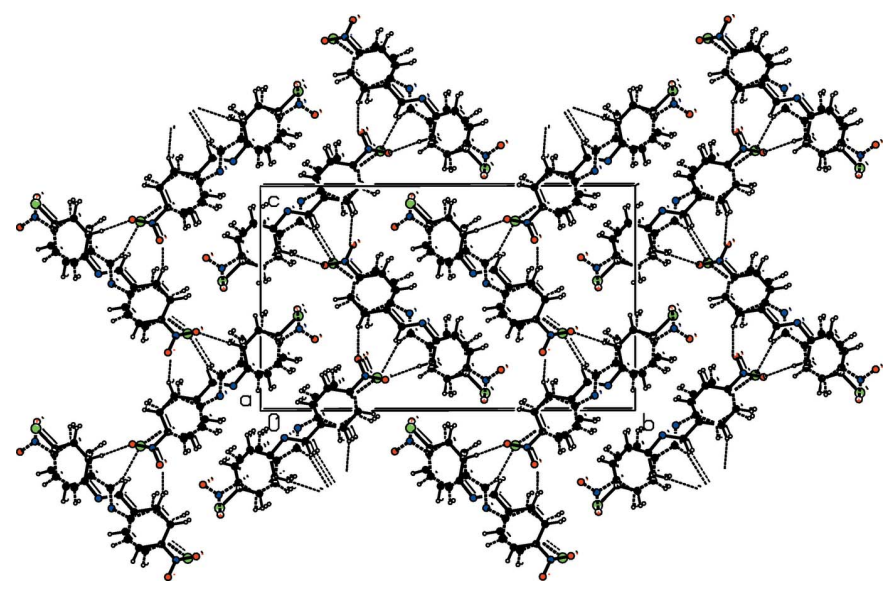

Figure 4

A view along the $a$ axis of the crystal packing of CNBA. The hydrogen bonds (see Table 1) are shown as dashed lines.
Table 1

Hydrogen-bond geometry $\left(\AA{ }^{\circ}\right)$.

\begin{tabular}{lllll}
\hline$D-\mathrm{H} \cdots A$ & $D-\mathrm{H}$ & $\mathrm{H} \cdots A$ & $D \cdots A$ & $D-\mathrm{H} \cdots A$ \\
\hline $\mathrm{C} 5-\mathrm{H} 5 \cdots \mathrm{O} 2^{\mathrm{i}}$ & 0.95 & 2.55 & $3.489(7)$ & 172 \\
$\mathrm{C} 13-\mathrm{H} 13 \cdots \mathrm{O} 1^{\mathrm{ii}}$ & 0.95 & 2.57 & $3.426(5)$ & 151 \\
$\mathrm{C}^{\mathrm{i}} 7-\mathrm{H} 27 \cdots \mathrm{C}^{\mathrm{i}}$ & 0.95 & 2.78 & $3.661(11)$ & 155 \\
\hline
\end{tabular}

Symmetry codes: (i) $x,-y+\frac{1}{2}, z-\frac{1}{2}$; (ii) $x+1,-y+\frac{1}{2}, z-\frac{1}{2}$.

packing for CNBA_1 is influenced by two $\mathrm{C}-\mathrm{H} \cdots \mathrm{O}$ interactions: namely, $\mathrm{C} 5-\mathrm{H} 5 \cdots \mathrm{O} 2$ and $\mathrm{C} 13-\mathrm{H} 13 \cdots \mathrm{O} 1$. The first of these links the molecules into $C(11)$ chains and the second generates $C(6)$ chains. In Fig. $5 b$, it can be seen that for CNBA_2 the molecular packing features weak $\mathrm{C}-\mathrm{H} \cdots \mathrm{Cl}$ interactions (Table 1). As a result of these interactions, corrugated layers are formed, lying parallel to the $a c$ plane.

\section{Database survey}

A search of the Cambridge Structural Database (Version 5.41, last update November 2019; Groom et al., 2016) for N,1-diphenylmethanimines gave 73 hits for 63 compounds, while a search for 1-(4-nitrophenyl)- $N$-phenylmethanimines gave 25 hits for six compounds. In these searches a number of compounds have multiple reports, or have been studied at different temperatures, or concern polymorphs.

The most relevant compounds that concern us here include those reported above in $\S 1$ (Chemical context), viz. $\mathrm{N}$-(4nitrobenzylidene)aniline (CSD refcodes QQQAIY01, QQQAIY02, QQQAIY03: Harada et al., 2004b), the 4-fluoro derivative (MIMDUJ: Subashini et al., 2013b), the 4-bromo derivative (FIBXIZ01: Subashini et al., 2013a), the 4-methyl derivative (NMBYAN: Filipenko et al., 1976; NMBYAN22: Filipenko et al., 1977; NMBYAN01: Cole et al., 2001; NMBYAN25, NMBYAN26: Harada et al., 2004a), the 4-methoxy benzylidene derivative (NMBZYA01, NMBZYA02: Harada et al., 2004a) and the 4-hydroxy derivative (WOTQED: Atioğlu et al., 2015).

For $N$-(4-nitrobenzylidene)aniline measured at $300 \mathrm{~K}$ (QQQAIY01), one of the two independent molecules in the asymmetric unit has type D1 disorder. At $200 \mathrm{~K}$ (QQQAIY02) a difference-Fourier map indicated only a few weak residual density peaks corresponding to the minor

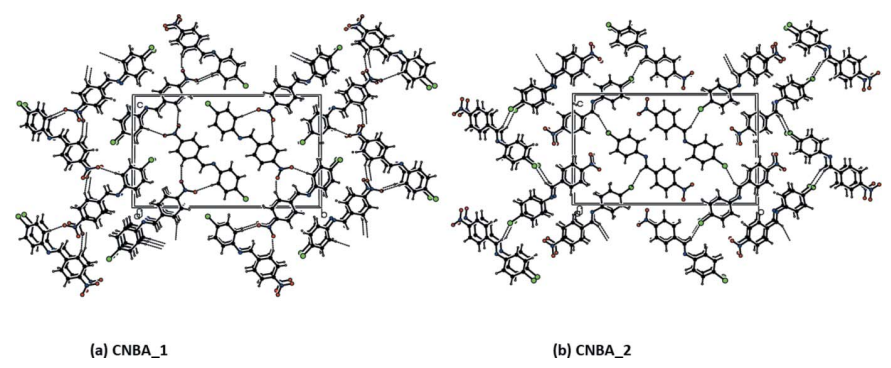

Figure 5

A view along the $a$ axis of the crystal packing of (a) the major disorder component and $(b)$ the minor component. The hydrogen bonds (see Table 1) are shown as dashed lines. 

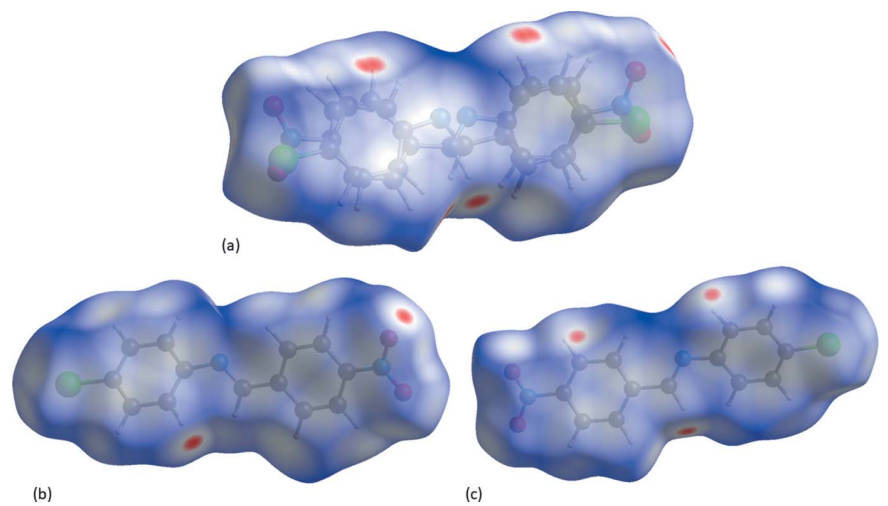

Figure 6

(a) The Hirshfeld surface of CNBA mapped over $d_{\text {norm }}$, in the colour range -0.15 to 1.13 a.u., $(b)$ the Hirshfeld surface of CNBA_1 mapped over $d_{\text {norm }}$, in the colour range -0.14 to 1.32 a.u., $(c)$ the Hirshfeld surface of CNBA_2 mapped over $d_{\text {norm }}$, in the colour range -0.15 to 1.29 a.u.

component, while at $90 \mathrm{~K}$ (QQQAIY03) no disorder was observed. For the 4-fluoro derivative measured at $173 \mathrm{~K}$ (MIMDUJ) no disorder was observed. For the 4-bromo derivative (FIBXIZ01), the crystals were incommensurate and twinned and the structure was refined in space group $A 2$. A triclinic polymorph of the 4-methyl derivative (NMBYAN) with two independent molecules in the asymmetric unit was reported on by Filipenko et al. (1976). A monoclinic polymorph, with one molecule in the asymmetric unit, was reported on first by Filipenko et al. (1976) for NMBYAN22, and later a neutron diffraction study at $20 \mathrm{~K}$ was carried out by Cole et al. (2001) for NMBYAN01. The triclinic polymorph was also studied by Harada et al. (2004a), at $300 \mathrm{~K}$ (NMBYAN25) and at $90 \mathrm{~K}$ (NMBYAN26) and showed only disorder of the methyl hydrogen atoms at both temperatures. The 4-methoxy benzylidene derivative, measured at $300 \mathrm{~K}$
(NMBZYA01) and $90 \mathrm{~K}$ (NMBZYA02), showed no disorder at either temperature. Finally, the 4-hydroxy derivative, WOTQED, crystallizes with four independent molecules in the asymmetric unit, and one of the molecules has type $D 1$ disorder.

The $\mathrm{N}=\mathrm{C}$ bond lengths vary from as short as $c a .1 .187 \AA$, in one of the four independent molecules of WOTQED, to $c a$ $1.281 \AA$ in NMBZYA02. In the title compound, the $\mathrm{N} 1=\mathrm{C} 7$ bond length in the major component is 1.291 (6) $\AA$, while for the minor component the $\mathrm{N} 21=\mathrm{C} 27$ bond length is 1.234 (12) $\AA$. In the above-mentioned compounds, the benzene rings are inclined to each other by dihedral angles varying from $\mathrm{ca} 2.24^{\circ}$ in one of the independent molecules of WOTQED to $c a 55.76^{\circ}$ in one of the two independent molecules in NMBYAN26; thus the dihedral angles for the disorder components of the title compound fall roughly in the middle of this range.

\section{Hirshfeld surface analysis and two-dimensional fingerprint plots}

The Hirshfeld surface analysis (Spackman \& Jayatilaka, 2009) and the associated two-dimensional fingerprint plots (McKinnon et al., 2007) were performed with CrystalExplorer17 (Turner et al., 2017) following the protocol of Tiekink and collaborators (Tan et al., 2019).

The Hirshfeld surface of CNBA mapped over $d_{\text {norm }}$ is given in Fig. $6 a$, where short interatomic contacts are indicated by the red spots. The Hirshfeld surfaces of the individual components, CNBA_1 and CNBA_2, mapped over $d_{\text {norm }}$ are given in Fig. $6 b$ and $6 c$, respectively.

The full two-dimensional fingerprint plots for CNBA and for the individual components, CNBA_1 and CNBA_2, are given in Fig. $7 a, 7 b$ and $7 c$, respectively. The relative percen-
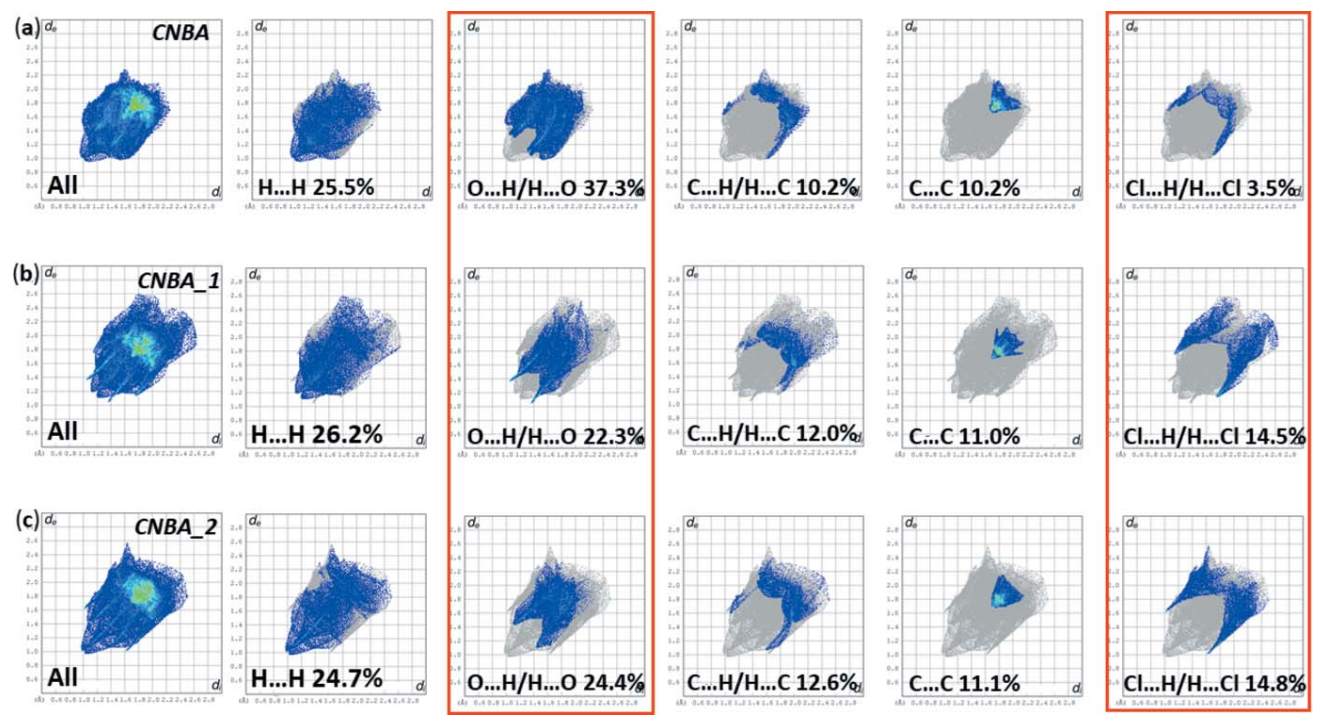

Figure 7

(a) The full two-dimensional fingerprint plot for CNBA, and fingerprint plots delineated into $\mathrm{H} \cdots \mathrm{H}, \mathrm{O} \cdots \mathrm{H} / \mathrm{H} \cdots \mathrm{O}, \mathrm{C} \cdots \mathrm{H} / \mathrm{H} \cdots \mathrm{C}, \mathrm{C} \cdots \mathrm{C}$ and $\mathrm{Cl} \cdots \mathrm{H} /$ $\mathrm{H} \cdots \mathrm{Cl}$ contacts, $(b)$ the full two-dimensional fingerprint plot for CNBA_1, and fingerprint plots delineated into $\mathrm{H} \cdots \mathrm{H}, \mathrm{O} \cdots \mathrm{H} / \mathrm{H} \cdots \mathrm{O}, \mathrm{C} \cdots \mathrm{H} / \mathrm{H} \cdots \mathrm{C}$, $\mathrm{C} \cdots \mathrm{C}$ and $\mathrm{Cl} \cdots \mathrm{H} / \mathrm{H} \cdots \mathrm{Cl}$ contacts, $(c)$ the full two-dimensional fingerprint plot for CNBA_2, and fingerprint plots delineated into $\mathrm{H} \cdots \mathrm{H}, \mathrm{O} \cdots \mathrm{H} / \mathrm{H} \cdots \mathrm{O}$, $\mathrm{C} \cdots \mathrm{H} / \mathrm{H} \cdots \mathrm{C}, \mathrm{C} \cdots \mathrm{C}$ and $\mathrm{Cl} \cdots \mathrm{H} / \mathrm{H} \cdots \mathrm{Cl}$ contacts. 
Table 2

Percentage contributions of interatomic contacts to the Hirshfeld surface for CNBA, and for the individual disordered components, CNBA_1 and CNBA_2.

\begin{tabular}{llll}
\hline Contact & \multicolumn{2}{l}{ Percentage contributions } \\
\hline & CNBA & CNBA_1 & CNBA_2 \\
$\mathrm{H} \cdots \mathrm{H}$ & 25.5 & 26.2 & 24.7 \\
$\mathrm{O} \cdots \mathrm{H} / \mathrm{H} \cdots \mathrm{O}$ & 37.3 & 22.3 & 24.4 \\
$\mathrm{Cl} \cdots \mathrm{H} / \mathrm{H} \cdots \mathrm{Cl}$ & 3.5 & 14.5 & 14.8 \\
$\mathrm{C} \cdots \mathrm{H} / \mathrm{H} \cdots \mathrm{C}$ & 10.2 & 12.0 & 12.6 \\
$\mathrm{C} \cdots \mathrm{C}$ & 10.2 & 11.0 & 11.1 \\
$\mathrm{~N} \cdots \mathrm{H} / \mathrm{H} \cdots \mathrm{N}$ & 3.5 & 4.2 & 3.4 \\
$\mathrm{C} \cdots \mathrm{N}$ & 3.2 & 2.4 & 2.4 \\
$\mathrm{O} \cdots \mathrm{O}$ & 2.3 & 0.3 & 0.6 \\
$\mathrm{C} \cdots \mathrm{O}$ & 1.6 & 1.9 & 0.7 \\
$\mathrm{O} \cdots \mathrm{Cl}$ & 0.8 & 2.0 & 1.4 \\
$\mathrm{C} \cdots \mathrm{Cl}$ & 0.4 & 1.0 & 1.9
\end{tabular}

tage contributions of close contacts to the Hirshfeld surface for CNBA and for the individual components are compared in Table 2. For CNBA the principal intermolecular interactions are delineated into $\mathrm{O} \cdots \mathrm{H} / \mathrm{H} \cdots \mathrm{O}$ at $37.3 \%, \mathrm{H} \cdots \mathrm{H}$ at $25.5 \%$, $\mathrm{C} \cdots \mathrm{H} / \mathrm{H} \cdots \mathrm{C}$ and $\mathrm{C} \cdots \mathrm{C}$ both at $10.2 \%$, followed by $\mathrm{Cl} \cdots \mathrm{H} /$ $\mathrm{H} \cdot \mathrm{Cl}$ and $\mathrm{N} \cdots \mathrm{H} / \mathrm{H} \cdots \mathrm{N}$ contacts both at $3.5 \%$. For CNBA_1 and CMBA_2 the order is somewhat different with $\mathrm{H} \cdots \mathrm{H}$ contributions being superior or almost equal to the contributions of the $\mathrm{O} \cdots \mathrm{H} / \mathrm{H} \cdots \mathrm{O}$ contacts, the latter contributions being 22.3 and $24.4 \%$, respectively, compared to $37.3 \%$ for CNBA. In contrast, the $\mathrm{Cl} \cdots \mathrm{H} / \mathrm{H} \cdots \mathrm{Cl}$ contacts contribute $14.5 \%$ and $14.8 \%$ for CNBA_1 and CNBA_2, respectively, compared to only $3.5 \%$ for CNBA. This situation reflects the details of the hydrogen bonding in the crystal structure (see Fig. $5 a$ and $5 b$, and Table 1 ).

\section{Synthesis and crystallization}

The commercially available organic compounds $p$-nitrobenzaldehyde and $p$-chloroaniline were used without further purification and the title compound was synthesized following reported procedures (Batra et al., 2004; Subashini et al., $2013 a$ ): the two reactants were taken in equimolar ratio and refluxed in ethanol for $6 \mathrm{~h}$. On cooling, the synthesized compound was deposited at room temperature as a deepyellow microcrystalline powder. The material was purified by repeated recrystallization using ethanol at room temperature and the purity of the sample was confirmed by thin layer chromatography. A saturated solution of CNBA was prepared using mixed solvents of ethanol and ethylacetate $(1: 1, v: v)$ and single crystals were obtained as yellow rods by slow evaporation of the solvents at room temperature over a period of 18 days. The ${ }^{1} \mathrm{H}$ NMR spectrum of CNBA recorded in $\mathrm{CDCl}_{3}$ is shown in the supporting information, Fig. $1 \mathrm{~S}$, and the FTIR and FT Raman spectra are shown in Fig. 2S.

\section{Refinement}

Crystal data, data collection and structure refinement details are summarized in Table 3. The $\mathrm{C}$-bound $\mathrm{H}$ atoms were included in calculated positions and refined as riding: $\mathrm{C}-\mathrm{H}=$
Table 3

Experimental details.

\begin{tabular}{|c|c|}
\hline \multicolumn{2}{|l|}{ Crystal data } \\
\hline Chemical formula & $\mathrm{C}_{13} \mathrm{H}_{9} \mathrm{ClN}_{2} \mathrm{O}_{2}$ \\
\hline$M_{\mathrm{r}}$ & 260.67 \\
\hline Crystal system, space group & Monoclinic, $P 2_{1} / c$ \\
\hline Temperature $(\mathrm{K})$ & 173 \\
\hline$a, b, c(\AA)$ & $3.8195(5), 22.826(4), 13.6381(19)$ \\
\hline$\beta\left({ }^{\circ}\right)$ & $92.829(11)$ \\
\hline$V\left(\mathrm{~A}^{3}\right)$ & $1187.6(3)$ \\
\hline$Z$ & 4 \\
\hline Radiation type & Мо $K \alpha$ \\
\hline$\mu\left(\mathrm{mm}^{-1}\right)$ & 0.32 \\
\hline Crystal size $(\mathrm{mm})$ & $0.34 \times 0.17 \times 0.09$ \\
\hline \multicolumn{2}{|l|}{ Data collection } \\
\hline Diffractometer & STOE IPDS2 \\
\hline Absorption correction & Multi-scan (MULABS; Spek, 2020) \\
\hline$T_{\min }, T_{\max }$ & $0.923,1.000$ \\
\hline $\begin{array}{l}\text { No. of measured, independent and } \\
\text { observed }[I>2 \sigma(I)] \text { reflections }\end{array}$ & $9572,2256,1498$ \\
\hline$R_{\text {int }}$ & 0.046 \\
\hline$(\sin \theta / \lambda)_{\max }\left(\AA^{-1}\right)$ & 0.610 \\
\hline \multicolumn{2}{|l|}{ Refinement } \\
\hline$R\left[F^{2}>2 \sigma\left(F^{2}\right)\right], w R\left(F^{2}\right), S$ & $0.049,0.121,0.98$ \\
\hline No. of reflections & 2256 \\
\hline No. of parameters & 206 \\
\hline $\mathrm{H}$-atom treatment & $\mathrm{H}$-atom parameters constrained \\
\hline$\Delta \rho_{\max }, \Delta \rho_{\min }\left(\mathrm{e} \AA^{-3}\right)$ & $0.30,-0.19$ \\
\hline
\end{tabular}

Computer programs: $X$-AREA and X-RED32 (Stoe \& Cie, 2006), SHELXS97 (Sheldrick, 2008), SHELXL2018 (Sheldrick, 2015), PLATON (Spek, 2020), Mercury (Macrae et al., 2020) and publCIF (Westrip, 2010).

$0.95 \AA$ with $U_{\text {iso }}(\mathrm{H})=1.2 U_{\text {eq }}(\mathrm{C})$. The molecule is disordered with an occupancy ratio that after refinement was fixed at 0.649: 0.351 . The benzene rings in the two components were refined as rigid bodies and the anisotropic displacement parameters of corresponding $\mathrm{C}$ atoms were made equal.

\section{Acknowledgements}

HSE is grateful to the University of Neuchâtel and the Swiss National Science Foundation for their support over the years.

\section{References}

Atioğlu, Z., Akkurt, M., Jarrahpour, A., Ebrahimi, E. \& Büyükgüngör, O. (2015). Acta Cryst. E71, o113-o114.

Bar, I. \& Bernstein, J. (1977). Acta Cryst. B33, 1738-1744.

Bar, I. \& Bernstein, J. (1982). Acta Cryst. B38, 121-125.

Bar, I. \& Bernstein, J. (1983). Acta Cryst. B39, 266-272.

Bar, I. \& Bernstein, J. (1984). J. Phys. Chem. 88, 243-248.

Batra, A. K., Gebre, T., Bhat, K., Aggarwal, M. D., Peterson, B., Sarkisov, S. \& Lal, R. B. (2004). Proc. SPIE, 5351, 57-68.

Behrnd, N.-R., Labat, G., Venugopalan, P., Hulliger, J. \& Bürgi, H.-B. (2010). Cryst. Growth Des. 10, 52-59.

Bernstein, J., Bar, I. \& Christensen, A. (1976). Acta Cryst. B32, 16091611.

Bernstein, J. \& Izak, I. (1976). J. Chem. Soc. Perkin Trans. 2, pp. 429 434.

Bernstein, J. \& Schmidt, G. M. (1972). J. Chem. Soc. Perkin Trans. 2, pp. 951-955.

Bürgi, H.-B. \& Dunitz, J. (1970). Helv. Chim. Acta, 53, 1747-1764.

Bushuyev, O. S., Friščić, T. \& Barrett, C. J. (2016). Cryst. Growth Des. 16, 541-545.

Cole, J. M., Howard, J. A. K. \& McIntyre, G. J. (2001). Acta Cryst. B57, 410-414. 
De Borger, R., Vande Velde, C. M. L. \& Blockhuys, F. (2005). Acta Cryst. E61, o819-o821.

Filipenko, O. S., Ponomarev, V. I. \& L.O.Atovmyan, L. O. (1976). Dokl. Akad. Nauk. SSSR, 229, 1113.

Filipenko, O. S., Shigorin, V. D., Ponomarev, V. I., Atovmyan, L. O., Safina, Z. Sh. \& Tarnopol'skii, B. L. (1977). Kristallografiya, 22, 534-.

Groom, C. R., Bruno, I. J., Lightfoot, M. P. \& Ward, S. C. (2016). Acta Cryst. B72, 171-179.

Harada, J., Harakawa, M. \& Ogawa, K. (2004a). Acta Cryst. B60, 578588.

Harada, J., Harakawa, M. \& Ogawa, K. (2004b). Acta Cryst. B60, 589597.

Huang, X.-J., Kuhn, G. H., Nesterov, V. N., Averkiev, B. B., Penn, B., Antipin, M. Yu. \& Timofeeva, T. V. (2002). Acta Cryst. C58, o624o628.

Kluge, S., Dohnke, I., Budde, F. \& Hulliger, J. (2003). CrystEngComm, 5, 67-69.

Macrae, C. F., Sovago, I., Cottrell, S. J., Galek, P. T. A., McCabe, P., Pidcock, E., Platings, M., Shields, G. P., Stevens, J. S., Towler, M. \& Wood, P. A. (2020). J. Appl. Cryst. 53, 226-235.
McKinnon, J. J., Jayatilaka, D. \& Spackman, M. A. (2007). Chem. Commun. pp. 3814-3816.

Sheldrick, G. M. (2008). Acta Cryst. A64, 112-122.

Sheldrick, G. M. (2015). Acta Cryst. C71, 3-8.

Spackman, M. A. \& Jayatilaka, D. (2009). CrystEngComm, 11, 19-32. Spek, A. L. (2020). Acta Cryst. E76, 1-11.

Stoe \& Cie. (2006). $X$-AREA and $X$-RED32. Stoe \& Cie GmbH, Darmstadt, Germany.

Subashini, A., Leela, S., Ramamurthi, K., Arakcheeva, A., StoeckliEvans, H. V., Petříček, V., Chapuis, G., Pattison, P. \& Reji, P. (2013a). CrystEngComm, 15, 2474-2481.

Subashini, A., Ramamurthi, K. \& Stoeckli-Evans, H. (2013b). Private Communication (refcode CCDC 940430). CCDC, Cambridge, England.

Tan, S. L., Jotani, M. M. \& Tiekink, E. R. T. (2019). Acta Cryst. E75, 308-318.

Turner, M. J., McKinnon, J. J., Wolff, S. K., Grimwood, D. J., Spackman, P. R., Jayatilaka, D. \& Spackman, M. A. (2017). CrystalExplorer17. University of Western Australia. http://hirshfeldsurface.net

Westrip, S. P. (2010). J. Appl. Cryst. 43, 920-925. 


\section{supporting information}

Acta Cryst. (2020). E76, 417-422 [https://doi.org/10.1107/S2056989020002212]

Whole-molecule disorder of the Schiff base compound 4-chloro-N-(4-nitro-

benzylidene)aniline: crystal structure and Hirshfeld surface analysis

Sundararaman Leela, Ashokkumar Subashini, Philip Reji, Kandasami Ramamurthi and Helen

Stoeckli-Evans

Computing details

Data collection: $X$-AREA (Stoe \& Cie, 2006); cell refinement: $X$-AREA (Stoe \& Cie, 2006); data reduction: X-RED32

(Stoe \& Cie, 2006); program(s) used to solve structure: SHELXS97 (Sheldrick, 2008); program(s) used to refine structure: SHELXL2018 (Sheldrick, 2015); molecular graphics: PLATON (Spek, 2020) and Mercury (Macrae et al., 2020); software used to prepare material for publication: SHELXL2018 (Sheldrick, 2015), PLATON (Spek, 2020) and publCIF (Westrip, 2010).

4-Chloro- $\mathrm{N}$-(4-nitrobenzylidene)aniline

Crystal data

$\mathrm{C}_{13} \mathrm{H}_{9} \mathrm{ClN}_{2} \mathrm{O}_{2}$

$M_{r}=260.67$

Monoclinic, $P 2_{1} / c$

$a=3.8195(5) \AA$

$b=22.826(4) \AA$

$c=13.6381(19) \AA$

$\beta=92.829(11)^{\circ}$

$V=1187.6(3) \AA^{3}$

$Z=4$

$F(000)=536$

$D_{\mathrm{x}}=1.458 \mathrm{Mg} \mathrm{m}^{-3}$

Mo $K \alpha$ radiation, $\lambda=0.71073 \AA$

Cell parameters from 3565 reflections

$\theta=1.7-26.0^{\circ}$

$\mu=0.32 \mathrm{~mm}^{-1}$

$T=173 \mathrm{~K}$

Rod, yellow

$0.34 \times 0.17 \times 0.09 \mathrm{~mm}$

Data collection

STOE IPDS-2

diffractometer

Radiation source: fine-focus sealed tube

Graphite monochromator

phi \& $\omega$ scans

Absorption correction: multi-scan

(MULABS; Spek, 2020)

$T_{\min }=0.923, T_{\max }=1.000$

9572 measured reflections

2256 independent reflections

1498 reflections with $I>2 \sigma(I)$

$R_{\text {int }}=0.046$

$\theta_{\text {max }}=25.7^{\circ}, \theta_{\min }=1.7^{\circ}$

$h=-4 \rightarrow 4$

$k=-27 \rightarrow 27$

$l=-16 \rightarrow 16$

Refinement

Refinement on $F^{2}$

Least-squares matrix: full

$R\left[F^{2}>2 \sigma\left(F^{2}\right)\right]=0.049$

$w R\left(F^{2}\right)=0.121$

$S=0.98$

2256 reflections

206 parameters

0 restraints

Primary atom site location: structure-invariant direct methods

Secondary atom site location: difference Fourier map

Hydrogen site location: inferred from neighbouring sites 
H-atom parameters constrained

$w=1 /\left[\sigma^{2}\left(F_{\mathrm{o}}^{2}\right)+(0.0668 P)^{2}\right]$

where $P=\left(F_{\mathrm{o}}^{2}+2 F_{\mathrm{c}}{ }^{2}\right) / 3$

$(\Delta / \sigma)_{\max }<0.001$

$\Delta \rho_{\max }=0.30$ e $\AA^{-3}$
$\Delta \rho_{\min }=-0.19$ e $\AA^{-3}$

Extinction correction: (SHELXL2018;

Sheldrick, 2015),

$\mathrm{Fc}^{*}=\mathrm{kFc}\left[1+0.001 \times \mathrm{xF}^{2} \lambda^{3} / \sin (2 \theta)\right]^{-1 / 4}$

Extinction coefficient: 0.036 (4)

Special details

Geometry. All esds (except the esd in the dihedral angle between two 1.s. planes) are estimated using the full covariance matrix. The cell esds are taken into account individually in the estimation of esds in distances, angles and torsion angles; correlations between esds in cell parameters are only used when they are defined by crystal symmetry. An approximate (isotropic) treatment of cell esds is used for estimating esds involving l.s. planes.

Fractional atomic coordinates and isotropic or equivalent isotropic displacement parameters $\left(\AA^{2}\right)$

\begin{tabular}{|c|c|c|c|c|c|}
\hline & $x$ & $y$ & $z$ & $U_{\text {iso }} * / U_{\text {eq }}$ & Occ. $(<1)$ \\
\hline $\mathrm{Cl1}$ & $1.0727(7)$ & $0.60002(12)$ & 0.0780 & $0.0575(7)$ & 0.649 \\
\hline $\mathrm{O} 1$ & $0.0813(9)$ & $0.23891(13)$ & $0.7308(2)$ & $0.0628(8)$ & 0.649 \\
\hline $\mathrm{O} 2$ & $0.212(2)$ & $0.1651(2)$ & $0.6402(7)$ & $0.069(2)$ & 0.649 \\
\hline N1 & $0.7162(7)$ & $0.42998(14)$ & $0.3862(3)$ & $0.0326(7)$ & 0.649 \\
\hline $\mathrm{N} 2$ & $0.1963(14)$ & $0.2188(2)$ & $0.6565(4)$ & $0.0444(13)$ & 0.649 \\
\hline $\mathrm{C} 1$ & $0.9720(11)$ & $0.54801(15)$ & $0.16579(17)$ & $0.0369(11)$ & 0.649 \\
\hline $\mathrm{C} 2$ & $1.0661(9)$ & $0.55941(11)$ & 0.26368 (19) & $0.0379(10)$ & 0.649 \\
\hline $\mathrm{H} 2$ & 1.184626 & 0.594746 & 0.281349 & $0.045^{*}$ & 0.649 \\
\hline $\mathrm{C} 3$ & $0.9869(8)$ & $0.51912(12)$ & $0.33572(13)$ & $0.0334(8)$ & 0.649 \\
\hline $\mathrm{H} 3$ & 1.051256 & 0.526918 & 0.402629 & $0.040 *$ & 0.649 \\
\hline $\mathrm{C} 4$ & $0.8136(8)$ & $0.46743(11)$ & $0.30987(16)$ & $0.0297(8)$ & 0.649 \\
\hline $\mathrm{C} 5$ & $0.7194(11)$ & $0.45602(14)$ & $0.21198(19)$ & $0.0353(10)$ & 0.649 \\
\hline H5 & 0.600963 & 0.420689 & 0.194313 & $0.042 *$ & 0.649 \\
\hline C6 & $0.7987(12)$ & $0.49631(18)$ & $0.13994(13)$ & $0.0391(11)$ & 0.649 \\
\hline H6 & 0.734329 & 0.488517 & 0.073031 & $0.047 *$ & 0.649 \\
\hline $\mathrm{C} 7$ & 0.7008 (13) & $0.3742(2)$ & $0.3713(5)$ & $0.0335(11)$ & 0.649 \\
\hline $\mathrm{H} 7$ & 0.774112 & 0.358824 & 0.310888 & $0.040 *$ & 0.649 \\
\hline $\mathrm{C} 8$ & $0.5727(10)$ & $0.33367(11)$ & 0.44542 (19) & $0.0305(10)$ & 0.649 \\
\hline C9 & $0.4512(9)$ & $0.35627(9)$ & $0.5321(2)$ & $0.0346(9)$ & 0.649 \\
\hline H9 & 0.451447 & 0.397391 & 0.542816 & $0.042 *$ & 0.649 \\
\hline $\mathrm{C} 10$ & $0.3292(9)$ & $0.31870(11)$ & $0.60298(18)$ & $0.0337(9)$ & 0.649 \\
\hline $\mathrm{H} 10$ & 0.246154 & 0.334147 & 0.662194 & $0.040 *$ & 0.649 \\
\hline $\mathrm{C} 11$ & $0.3289(11)$ & $0.25854(11)$ & $0.5872(2)$ & $0.0278(9)$ & 0.649 \\
\hline $\mathrm{C} 12$ & $0.4504(13)$ & $0.23594(9)$ & $0.5006(3)$ & $0.0331(10)$ & 0.649 \\
\hline H12 & 0.450148 & 0.194817 & 0.489855 & $0.040 *$ & 0.649 \\
\hline $\mathrm{C} 13$ & $0.5724(12)$ & $0.27351(12)$ & $0.4297(2)$ & $0.0333(10)$ & 0.649 \\
\hline H13 & 0.655443 & 0.258061 & 0.370476 & $0.040^{*}$ & 0.649 \\
\hline $\mathrm{Cl} 2$ & $0.1792(12)$ & $0.1871(2)$ & $0.6481(4)$ & $0.0553(12)$ & 0.351 \\
\hline $\mathrm{O} 21$ & $1.1934(18)$ & $0.6433(2)$ & $0.1833(4)$ & $0.0704(17)$ & 0.351 \\
\hline $\mathrm{O} 22$ & $1.091(5)$ & $0.5975(7)$ & $0.0487(13)$ & $0.099(8)$ & 0.351 \\
\hline $\mathrm{N} 21$ & $0.6719(15)$ & $0.3947(3)$ & $0.4304(6)$ & $0.0429(14)$ & 0.351 \\
\hline $\mathrm{N} 22$ & $1.095(2)$ & $0.6024(4)$ & $0.1364(8)$ & $0.053(2)$ & 0.351 \\
\hline $\mathrm{C} 21$ & $0.331(3)$ & $0.2457(2)$ & $0.5774(7)$ & $0.0369(11)$ & 0.351 \\
\hline $\mathrm{C} 22$ & $0.476(3)$ & $0.2384(3)$ & $0.4867(7)$ & $0.0379(10)$ & 0.351 \\
\hline
\end{tabular}




$\begin{array}{llllll}\mathrm{H} 22 & 0.496956 & 0.200313 & 0.459614 & 0.045^{*} & 0.351 \\ \mathrm{C} 23 & 0.590(3) & 0.2869(4) & 0.4356(5) & 0.0334(8) & 0.351 \\ \mathrm{H} 23 & 0.689079 & 0.281974 & 0.373553 & 0.040^{*} & 0.351 \\ \mathrm{C} 24 & 0.559(2) & 0.3427(3) & 0.4752(5) & 0.0297(8) & 0.351 \\ \mathrm{C} 25 & 0.414(2) & 0.3500(2) & 0.5659(5) & 0.0353(10) & 0.351 \\ \mathrm{H} 25 & 0.393402 & 0.388076 & 0.592940 & 0.042^{*} & 0.351 \\ \mathrm{C} 26 & 0.300(2) & 0.3015(3) & 0.6170(4) & 0.0391(11) & 0.351 \\ \mathrm{H} 26 & 0.201277 & 0.306416 & 0.679004 & 0.047^{*} & 0.351 \\ \mathrm{C} 27 & 0.652(2) & 0.3978(5) & 0.3399(7) & 0.039(2) & 0.351 \\ \mathrm{H} 27 & 0.556380 & 0.365770 & 0.303238 & 0.047^{*} & 0.351 \\ \mathrm{C} 28 & 0.7743(17) & 0.4503(2) & 0.2864(5) & 0.0305(10) & 0.351 \\ \mathrm{C} 29 & 0.9255(16) & 0.4963(3) & 0.3401(3) & 0.0346(9) & 0.351 \\ \mathrm{H} 29 & 0.953565 & 0.493632 & 0.409583 & 0.042^{*} & 0.351 \\ \mathrm{C} 30 & 1.0355(18) & 0.5463(2) & 0.2922(5) & 0.0337(9) & 0.351 \\ \mathrm{H} 30 & 1.138834 & 0.577751 & 0.328889 & 0.040^{*} & 0.351 \\ \mathrm{C} 31 & 0.994(2) & 0.5502(3) & 0.1906(5) & 0.0278(9) & 0.351 \\ \mathrm{C} 32 & 0.843(2) & 0.5042(4) & 0.1369(3) & 0.0331(10) & 0.351 \\ \mathrm{H} 32 & 0.815122 & 0.506868 & 0.067426 & 0.040^{*} & 0.351 \\ \mathrm{C} 33 & 0.733(2) & 0.4542(3) & 0.1848(5) & 0.0333(10) & 0.351 \\ \mathrm{H} 33 & 0.629851 & 0.422748 & 0.148118 & 0.040^{*} & 0.351\end{array}$

Atomic displacement parameters $\left(\AA^{2}\right)$

\begin{tabular}{lllllll}
\hline & $U^{11}$ & $U^{22}$ & $U^{33}$ & $U^{12}$ & $U^{13}$ & $U^{23}$ \\
\hline C11 & $0.0600(10)$ & $0.0436(10)$ & $0.070(2)$ & $0.0011(8)$ & $0.0144(12)$ & $0.0180(13)$ \\
O1 & $0.080(2)$ & $0.070(2)$ & $0.0402(16)$ & $-0.0056(16)$ & $0.0215(16)$ & $0.0067(15)$ \\
O2 & $0.086(4)$ & $0.044(4)$ & $0.078(3)$ & $0.004(3)$ & $0.019(3)$ & $0.017(3)$ \\
N1 & $0.0346(17)$ & $0.0294(16)$ & $0.0340(17)$ & $-0.0007(13)$ & $0.0049(13)$ & $0.0029(17)$ \\
N2 & $0.039(2)$ & $0.048(3)$ & $0.046(2)$ & $0.005(3)$ & $-0.0023(16)$ & $0.014(3)$ \\
C1 & $0.038(2)$ & $0.0319(18)$ & $0.040(2)$ & $0.0038(16)$ & $0.000(2)$ & $-0.0006(18)$ \\
C2 & $0.039(2)$ & $0.0315(18)$ & $0.044(3)$ & $0.0009(15)$ & $0.0093(17)$ & $0.0016(15)$ \\
C3 & $0.0362(19)$ & $0.0280(18)$ & $0.0363(19)$ & $-0.0026(14)$ & $0.0043(15)$ & $0.0024(14)$ \\
C4 & $0.0270(17)$ & $0.0295(18)$ & $0.0327(19)$ & $0.0002(14)$ & $0.0011(15)$ & $-0.0044(17)$ \\
C5 & $0.0339(19)$ & $0.0328(19)$ & $0.039(3)$ & $-0.0006(14)$ & $0.0036(18)$ & $0.0001(18)$ \\
C6 & $0.036(2)$ & $0.039(2)$ & $0.043(2)$ & $-0.0028(17)$ & $0.0006(16)$ & $0.0048(17)$ \\
C7 & $0.029(2)$ & $0.037(3)$ & $0.034(3)$ & $0.005(2)$ & $0.0000(19)$ & $-0.001(2)$ \\
C8 & $0.0267(16)$ & $0.035(2)$ & $0.0289(19)$ & $-0.0004(14)$ & $-0.0039(16)$ & $-0.0050(16)$ \\
C9 & $0.0364(19)$ & $0.0323(17)$ & $0.035(2)$ & $-0.0008(14)$ & $0.0005(17)$ & $0.0035(15)$ \\
C10 & $0.0367(19)$ & $0.0319(19)$ & $0.0320(18)$ & $0.0049(16)$ & $-0.0027(15)$ & $-0.0071(16)$ \\
C11 & $0.0271(19)$ & $0.029(2)$ & $0.0267(17)$ & $0.0014(15)$ & $-0.0009(14)$ & $0.0031(16)$ \\
C12 & $0.032(2)$ & $0.0383(19)$ & $0.030(2)$ & $0.0029(15)$ & $0.0022(16)$ & $0.0033(15)$ \\
C13 & $0.0344(19)$ & $0.033(2)$ & $0.0329(18)$ & $0.0014(17)$ & $0.0026(15)$ & $0.0015(15)$ \\
C12 & $0.0509(15)$ & $0.057(4)$ & $0.058(2)$ & $0.007(3)$ & $0.0044(13)$ & $0.023(3)$ \\
O21 & $0.101(5)$ & $0.041(3)$ & $0.069(4)$ & $-0.019(3)$ & $0.007(3)$ & $-0.008(3)$ \\
O22 & $0.153(13)$ & $0.064(7)$ & $0.079(12)$ & $-0.017(6)$ & $-0.015(8)$ & $-0.009(6)$ \\
N21 & $0.036(3)$ & $0.040(4)$ & $0.053(4)$ & $0.002(3)$ & $0.001(3)$ & $-0.004(4)$ \\
N22 & $0.045(4)$ & $0.052(5)$ & $0.063(6)$ & $-0.014(3)$ & $0.010(5)$ & $-0.018(5)$ \\
C21 & $0.038(2)$ & $0.0319(18)$ & $0.040(2)$ & $0.0038(16)$ & $0.000(2)$ & $-0.0006(18)$ \\
& & & & &
\end{tabular}


supporting information

\begin{tabular}{lllllll}
\hline & & & & & \\
C22 & $0.039(2)$ & $0.0315(18)$ & $0.044(3)$ & $0.0009(15)$ & $0.0093(17)$ & $0.0016(15)$ \\
C23 & $0.0362(19)$ & $0.0280(18)$ & $0.0363(19)$ & $-0.0026(14)$ & $0.0043(15)$ & $0.0024(14)$ \\
C24 & $0.0270(17)$ & $0.0295(18)$ & $0.0327(19)$ & $0.0002(14)$ & $0.0011(15)$ & $-0.0044(17)$ \\
C25 & $0.0339(19)$ & $0.0328(19)$ & $0.039(3)$ & $-0.0006(14)$ & $0.0036(18)$ & $0.0001(18)$ \\
C26 & $0.036(2)$ & $0.039(2)$ & $0.043(2)$ & $-0.0028(17)$ & $0.0006(16)$ & $0.0048(17)$ \\
C27 & $0.029(4)$ & $0.041(6)$ & $0.048(6)$ & $0.003(4)$ & $0.001(4)$ & $-0.010(5)$ \\
C28 & $0.0267(16)$ & $0.035(2)$ & $0.0289(19)$ & $-0.0004(14)$ & $-0.0039(16)$ & $-0.0050(16)$ \\
C29 & $0.0364(19)$ & $0.0323(17)$ & $0.035(2)$ & $-0.0008(14)$ & $0.0005(17)$ & $0.0035(15)$ \\
C30 & $0.0367(19)$ & $0.0319(19)$ & $0.0320(18)$ & $0.0049(16)$ & $-0.0027(15)$ & $-0.0071(16)$ \\
C31 & $0.0271(19)$ & $0.029(2)$ & $0.0267(17)$ & $0.0014(15)$ & $-0.0009(14)$ & $0.0031(16)$ \\
C32 & $0.032(2)$ & $0.0383(19)$ & $0.030(2)$ & $0.0029(15)$ & $0.0022(16)$ & $0.0033(15)$ \\
C33 & $0.0344(19)$ & $0.033(2)$ & $0.0329(18)$ & $0.0014(17)$ & $0.0026(15)$ & $0.0015(15)$ \\
& & & & & & \\
\hline
\end{tabular}

Geometric parameters $\left(\AA,{ }^{\circ}\right)$

\begin{tabular}{|c|c|c|c|}
\hline $\mathrm{Cl} 1-\mathrm{C} 1$ & $1.743(4)$ & $\mathrm{C} 12-\mathrm{C} 21$ & $1.763(7)$ \\
\hline $\mathrm{O} 1-\mathrm{N} 2$ & $1.214(6)$ & $\mathrm{O} 21-\mathrm{N} 22$ & $1.182(9)$ \\
\hline $\mathrm{O} 2-\mathrm{N} 2$ & $1.248(7)$ & $\mathrm{O} 22-\mathrm{N} 22$ & $1.20(2)$ \\
\hline $\mathrm{N} 1-\mathrm{C} 7$ & $1.291(6)$ & $\mathrm{N} 21-\mathrm{C} 27$ & $1.234(12)$ \\
\hline $\mathrm{N} 1-\mathrm{C} 4$ & $1.411(4)$ & $\mathrm{N} 21-\mathrm{C} 24$ & $1.412(9)$ \\
\hline $\mathrm{N} 2-\mathrm{C} 11$ & $1.420(6)$ & $\mathrm{N} 22-\mathrm{C} 31$ & $1.462(11)$ \\
\hline $\mathrm{C} 1-\mathrm{C} 2$ & 1.3900 & $\mathrm{C} 21-\mathrm{C} 22$ & 1.3900 \\
\hline $\mathrm{C} 1-\mathrm{C} 6$ & 1.3900 & $\mathrm{C} 21-\mathrm{C} 26$ & 1.3900 \\
\hline $\mathrm{C} 2-\mathrm{C} 3$ & 1.3900 & $\mathrm{C} 22-\mathrm{C} 23$ & 1.3900 \\
\hline $\mathrm{C} 2-\mathrm{H} 2$ & 0.9500 & $\mathrm{C} 22-\mathrm{H} 22$ & 0.9500 \\
\hline $\mathrm{C} 3-\mathrm{C} 4$ & 1.3900 & $\mathrm{C} 23-\mathrm{C} 24$ & 1.3900 \\
\hline $\mathrm{C} 3-\mathrm{H} 3$ & 0.9500 & $\mathrm{C} 23-\mathrm{H} 23$ & 0.9500 \\
\hline $\mathrm{C} 4-\mathrm{C} 5$ & 1.3900 & $\mathrm{C} 24-\mathrm{C} 25$ & 1.3900 \\
\hline $\mathrm{C} 5-\mathrm{C} 6$ & 1.3900 & $\mathrm{C} 25-\mathrm{C} 26$ & 1.3900 \\
\hline $\mathrm{C} 5-\mathrm{H} 5$ & 0.9500 & $\mathrm{C} 25-\mathrm{H} 25$ & 0.9500 \\
\hline $\mathrm{C} 6-\mathrm{H} 6$ & 0.9500 & $\mathrm{C} 26-\mathrm{H} 26$ & 0.9500 \\
\hline $\mathrm{C} 7-\mathrm{C} 8$ & $1.471(6)$ & $\mathrm{C} 27-\mathrm{C} 28$ & $1.488(11)$ \\
\hline $\mathrm{C} 7-\mathrm{H} 7$ & 0.9500 & $\mathrm{C} 27-\mathrm{H} 27$ & 0.9500 \\
\hline $\mathrm{C} 8-\mathrm{C} 9$ & 1.3900 & $\mathrm{C} 28-\mathrm{C} 29$ & 1.3900 \\
\hline $\mathrm{C} 8-\mathrm{C} 13$ & 1.3900 & $\mathrm{C} 28-\mathrm{C} 33$ & 1.3900 \\
\hline $\mathrm{C} 9-\mathrm{C} 10$ & 1.3900 & $\mathrm{C} 29-\mathrm{C} 30$ & 1.3900 \\
\hline C9-H9 & 0.9500 & $\mathrm{C} 29-\mathrm{H} 29$ & 0.9500 \\
\hline $\mathrm{C} 10-\mathrm{C} 11$ & 1.3900 & $\mathrm{C} 30-\mathrm{C} 31$ & 1.3900 \\
\hline $\mathrm{C} 10-\mathrm{H} 10$ & 0.9500 & $\mathrm{C} 30-\mathrm{H} 30$ & 0.9500 \\
\hline $\mathrm{C} 11-\mathrm{C} 12$ & 1.3900 & $\mathrm{C} 31-\mathrm{C} 32$ & 1.3900 \\
\hline $\mathrm{C} 12-\mathrm{C} 13$ & 1.3900 & $\mathrm{C} 32-\mathrm{C} 33$ & 1.3900 \\
\hline $\mathrm{C} 12-\mathrm{H} 12$ & 0.9500 & C $32-\mathrm{H} 32$ & 0.9500 \\
\hline $\mathrm{C} 13-\mathrm{H} 13$ & 0.9500 & $\mathrm{C} 33-\mathrm{H} 33$ & 0.9500 \\
\hline $\mathrm{C} 7-\mathrm{N} 1-\mathrm{C} 4$ & $119.5(4)$ & $\mathrm{C} 27-\mathrm{N} 21-\mathrm{C} 24$ & $118.5(9)$ \\
\hline $\mathrm{O} 1-\mathrm{N} 2-\mathrm{O} 2$ & $122.8(8)$ & $\mathrm{O} 21-\mathrm{N} 22-\mathrm{O} 22$ & $126.8(14)$ \\
\hline $\mathrm{O} 1-\mathrm{N} 2-\mathrm{C} 11$ & $117.9(4)$ & $\mathrm{O} 21-\mathrm{N} 22-\mathrm{C} 31$ & $117.0(9)$ \\
\hline $\mathrm{O} 2-\mathrm{N} 2-\mathrm{C} 11$ & $119.2(8)$ & $\mathrm{O} 22-\mathrm{N} 22-\mathrm{C} 31$ & $115.9(12)$ \\
\hline
\end{tabular}




\begin{tabular}{|c|c|c|c|}
\hline $\mathrm{C} 2-\mathrm{C} 1-\mathrm{C} 6$ & 120.0 & $\mathrm{C} 22-\mathrm{C} 21-\mathrm{C} 26$ & 120.0 \\
\hline $\mathrm{C} 2-\mathrm{C} 1-\mathrm{C} 11$ & $118.5(2)$ & $\mathrm{C} 22-\mathrm{C} 21-\mathrm{C} 12$ & $123.6(5)$ \\
\hline $\mathrm{C} 6-\mathrm{C} 1-\mathrm{Cl1}$ & $121.5(2)$ & $\mathrm{C} 26-\mathrm{C} 21-\mathrm{Cl} 2$ & $116.4(5)$ \\
\hline $\mathrm{C} 3-\mathrm{C} 2-\mathrm{C} 1$ & 120.0 & $\mathrm{C} 23-\mathrm{C} 22-\mathrm{C} 21$ & 120.0 \\
\hline $\mathrm{C} 3-\mathrm{C} 2-\mathrm{H} 2$ & 120.0 & $\mathrm{C} 23-\mathrm{C} 22-\mathrm{H} 22$ & 120.0 \\
\hline $\mathrm{C} 1-\mathrm{C} 2-\mathrm{H} 2$ & 120.0 & $\mathrm{C} 21-\mathrm{C} 22-\mathrm{H} 22$ & 120.0 \\
\hline $\mathrm{C} 2-\mathrm{C} 3-\mathrm{C} 4$ & 120.0 & $\mathrm{C} 22-\mathrm{C} 23-\mathrm{C} 24$ & 120.0 \\
\hline $\mathrm{C} 2-\mathrm{C} 3-\mathrm{H} 3$ & 120.0 & $\mathrm{C} 22-\mathrm{C} 23-\mathrm{H} 23$ & 120.0 \\
\hline $\mathrm{C} 4-\mathrm{C} 3-\mathrm{H} 3$ & 120.0 & $\mathrm{C} 24-\mathrm{C} 23-\mathrm{H} 23$ & 120.0 \\
\hline $\mathrm{C} 5-\mathrm{C} 4-\mathrm{C} 3$ & 120.0 & $\mathrm{C} 25-\mathrm{C} 24-\mathrm{C} 23$ & 120.0 \\
\hline $\mathrm{C} 5-\mathrm{C} 4-\mathrm{N} 1$ & $122.0(2)$ & $\mathrm{C} 25-\mathrm{C} 24-\mathrm{N} 21$ & $115.4(6)$ \\
\hline $\mathrm{C} 3-\mathrm{C} 4-\mathrm{N} 1$ & $117.8(2)$ & $\mathrm{C} 23-\mathrm{C} 24-\mathrm{N} 21$ & $124.6(6)$ \\
\hline $\mathrm{C} 4-\mathrm{C} 5-\mathrm{C} 6$ & 120.0 & $\mathrm{C} 24-\mathrm{C} 25-\mathrm{C} 26$ & 120.0 \\
\hline $\mathrm{C} 4-\mathrm{C} 5-\mathrm{H} 5$ & 120.0 & $\mathrm{C} 24-\mathrm{C} 25-\mathrm{H} 25$ & 120.0 \\
\hline $\mathrm{C} 6-\mathrm{C} 5-\mathrm{H} 5$ & 120.0 & $\mathrm{C} 26-\mathrm{C} 25-\mathrm{H} 25$ & 120.0 \\
\hline $\mathrm{C} 5-\mathrm{C} 6-\mathrm{C} 1$ & 120.0 & $\mathrm{C} 25-\mathrm{C} 26-\mathrm{C} 21$ & 120.0 \\
\hline $\mathrm{C} 5-\mathrm{C} 6-\mathrm{H} 6$ & 120.0 & $\mathrm{C} 25-\mathrm{C} 26-\mathrm{H} 26$ & 120.0 \\
\hline $\mathrm{C} 1-\mathrm{C} 6-\mathrm{H} 6$ & 120.0 & $\mathrm{C} 21-\mathrm{C} 26-\mathrm{H} 26$ & 120.0 \\
\hline $\mathrm{N} 1-\mathrm{C} 7-\mathrm{C} 8$ & $121.7(5)$ & $\mathrm{N} 21-\mathrm{C} 27-\mathrm{C} 28$ & $122.1(10)$ \\
\hline $\mathrm{N} 1-\mathrm{C} 7-\mathrm{H} 7$ & 119.1 & $\mathrm{~N} 21-\mathrm{C} 27-\mathrm{H} 27$ & 118.9 \\
\hline $\mathrm{C} 8-\mathrm{C} 7-\mathrm{H} 7$ & 119.1 & $\mathrm{C} 28-\mathrm{C} 27-\mathrm{H} 27$ & 118.9 \\
\hline $\mathrm{C} 9-\mathrm{C} 8-\mathrm{C} 13$ & 120.0 & $\mathrm{C} 29-\mathrm{C} 28-\mathrm{C} 33$ & 120.0 \\
\hline $\mathrm{C} 9-\mathrm{C} 8-\mathrm{C} 7$ & $119.2(3)$ & $\mathrm{C} 29-\mathrm{C} 28-\mathrm{C} 27$ & $118.8(6)$ \\
\hline $\mathrm{C} 13-\mathrm{C} 8-\mathrm{C} 7$ & $120.8(3)$ & $\mathrm{C} 33-\mathrm{C} 28-\mathrm{C} 27$ & $121.2(6)$ \\
\hline $\mathrm{C} 8-\mathrm{C} 9-\mathrm{C} 10$ & 120.0 & $\mathrm{C} 28-\mathrm{C} 29-\mathrm{C} 30$ & 120.0 \\
\hline $\mathrm{C} 8-\mathrm{C} 9-\mathrm{H} 9$ & 120.0 & $\mathrm{C} 28-\mathrm{C} 29-\mathrm{H} 29$ & 120.0 \\
\hline $\mathrm{C} 10-\mathrm{C} 9-\mathrm{H} 9$ & 120.0 & $\mathrm{C} 30-\mathrm{C} 29-\mathrm{H} 29$ & 120.0 \\
\hline $\mathrm{C} 11-\mathrm{C} 10-\mathrm{C} 9$ & 120.0 & $\mathrm{C} 31-\mathrm{C} 30-\mathrm{C} 29$ & 120.0 \\
\hline $\mathrm{C} 11-\mathrm{C} 10-\mathrm{H} 10$ & 120.0 & $\mathrm{C} 31-\mathrm{C} 30-\mathrm{H} 30$ & 120.0 \\
\hline $\mathrm{C} 9-\mathrm{C} 10-\mathrm{H} 10$ & 120.0 & $\mathrm{C} 29-\mathrm{C} 30-\mathrm{H} 30$ & 120.0 \\
\hline $\mathrm{C} 10-\mathrm{C} 11-\mathrm{C} 12$ & 120.0 & $\mathrm{C} 30-\mathrm{C} 31-\mathrm{C} 32$ & 120.0 \\
\hline $\mathrm{C} 10-\mathrm{C} 11-\mathrm{N} 2$ & $121.8(3)$ & $\mathrm{C} 30-\mathrm{C} 31-\mathrm{N} 22$ & $122.4(7)$ \\
\hline $\mathrm{C} 12-\mathrm{C} 11-\mathrm{N} 2$ & $118.2(3)$ & $\mathrm{C} 32-\mathrm{C} 31-\mathrm{N} 22$ & $117.5(7)$ \\
\hline $\mathrm{C} 13-\mathrm{C} 12-\mathrm{C} 11$ & 120.0 & $\mathrm{C} 33-\mathrm{C} 32-\mathrm{C} 31$ & 120.0 \\
\hline $\mathrm{C} 13-\mathrm{C} 12-\mathrm{H} 12$ & 120.0 & $\mathrm{C} 33-\mathrm{C} 32-\mathrm{H} 32$ & 120.0 \\
\hline $\mathrm{C} 11-\mathrm{C} 12-\mathrm{H} 12$ & 120.0 & $\mathrm{C} 31-\mathrm{C} 32-\mathrm{H} 32$ & 120.0 \\
\hline $\mathrm{C} 12-\mathrm{C} 13-\mathrm{C} 8$ & 120.0 & $\mathrm{C} 32-\mathrm{C} 33-\mathrm{C} 28$ & 120.0 \\
\hline $\mathrm{C} 12-\mathrm{C} 13-\mathrm{H} 13$ & 120.0 & $\mathrm{C} 32-\mathrm{C} 33-\mathrm{H} 33$ & 120.0 \\
\hline $\mathrm{C} 8-\mathrm{C} 13-\mathrm{H} 13$ & 120.0 & $\mathrm{C} 28-\mathrm{C} 33-\mathrm{H} 33$ & 120.0 \\
\hline $\mathrm{C} 6-\mathrm{C} 1-\mathrm{C} 2-\mathrm{C} 3$ & 0.0 & $\mathrm{C} 26-\mathrm{C} 21-\mathrm{C} 22-\mathrm{C} 23$ & 0.0 \\
\hline $\mathrm{C} 11-\mathrm{C} 1-\mathrm{C} 2-\mathrm{C} 3$ & $179.4(3)$ & $\mathrm{C} 12-\mathrm{C} 21-\mathrm{C} 22-\mathrm{C} 23$ & $-179.9(8)$ \\
\hline $\mathrm{C} 1-\mathrm{C} 2-\mathrm{C} 3-\mathrm{C} 4$ & 0.0 & $\mathrm{C} 21-\mathrm{C} 22-\mathrm{C} 23-\mathrm{C} 24$ & 0.0 \\
\hline $\mathrm{C} 2-\mathrm{C} 3-\mathrm{C} 4-\mathrm{C} 5$ & 0.0 & $\mathrm{C} 22-\mathrm{C} 23-\mathrm{C} 24-\mathrm{C} 25$ & 0.0 \\
\hline $\mathrm{C} 2-\mathrm{C} 3-\mathrm{C} 4-\mathrm{N} 1$ & $-175.4(3)$ & $\mathrm{C} 22-\mathrm{C} 23-\mathrm{C} 24-\mathrm{N} 21$ & $178.9(8)$ \\
\hline $\mathrm{C} 7-\mathrm{N} 1-\mathrm{C} 4-\mathrm{C} 5$ & $34.9(4)$ & $\mathrm{C} 27-\mathrm{N} 21-\mathrm{C} 24-\mathrm{C} 25$ & $-147.7(7)$ \\
\hline $\mathrm{C} 7-\mathrm{N} 1-\mathrm{C} 4-\mathrm{C} 3$ & $-149.8(4)$ & $\mathrm{C} 27-\mathrm{N} 21-\mathrm{C} 24-\mathrm{C} 23$ & $33.4(10)$ \\
\hline $\mathrm{C} 3-\mathrm{C} 4-\mathrm{C} 5-\mathrm{C} 6$ & 0.0 & $\mathrm{C} 23-\mathrm{C} 24-\mathrm{C} 25-\mathrm{C} 26$ & 0.0 \\
\hline
\end{tabular}




$\begin{array}{ll}\mathrm{N} 1-\mathrm{C} 4-\mathrm{C} 5-\mathrm{C} 6 & 175.2(3) \\ \mathrm{C} 4-\mathrm{C} 5-\mathrm{C} 6-\mathrm{C} 1 & 0.0 \\ \mathrm{C} 2-\mathrm{C} 1-\mathrm{C} 6-\mathrm{C} 5 & 0.0 \\ \mathrm{C} 11-\mathrm{C} 1-\mathrm{C} 6-\mathrm{C} 5 & -179.4(3) \\ \mathrm{C} 4-\mathrm{N} 1-\mathrm{C} 7-\mathrm{C} 8 & -174.8(3) \\ \mathrm{N} 1-\mathrm{C} 7-\mathrm{C} 8-\mathrm{C} 9 & 2.8(6) \\ \mathrm{N} 1-\mathrm{C} 7-\mathrm{C} 8-\mathrm{C} 13 & -177.2(4) \\ \mathrm{C} 13-\mathrm{C} 8-\mathrm{C} 9-\mathrm{C} 10 & 0.0 \\ \mathrm{C} 7-\mathrm{C} 8-\mathrm{C} 9-\mathrm{C} 10 & -180.0(4) \\ \mathrm{C} 8-\mathrm{C} 9-\mathrm{C} 10-\mathrm{C} 11 & 0.0 \\ \mathrm{C} 9-\mathrm{C} 10-\mathrm{C} 11-\mathrm{C} 12 & 0.0 \\ \mathrm{C} 9-\mathrm{C} 10-\mathrm{C} 11-\mathrm{N} 2 & -178.0(4) \\ \mathrm{O} 1-\mathrm{N} 2-\mathrm{C} 11-\mathrm{C} 10 & 0.1(6) \\ \mathrm{O} 2-\mathrm{N} 2-\mathrm{C} 11-\mathrm{C} 10 & -177.9(7) \\ \mathrm{O} 1-\mathrm{N} 2-\mathrm{C} 11-\mathrm{C} 12 & -178.0(4) \\ \mathrm{O} 2-\mathrm{N} 2-\mathrm{C} 11-\mathrm{C} 12 & 4.1(9) \\ \mathrm{C} 10-\mathrm{C} 11-\mathrm{C} 12-\mathrm{C} 13 & 0.0 \\ \mathrm{~N} 2-\mathrm{C} 11-\mathrm{C} 12-\mathrm{C} 13 & 178.1(4) \\ \mathrm{C} 11-\mathrm{C} 12-\mathrm{C} 13-\mathrm{C} 8 & 0.0 \\ \mathrm{C} 9-\mathrm{C} 8-\mathrm{C} 13-\mathrm{C} 12 & 0.0 \\ \mathrm{C} 7-\mathrm{C} 8-\mathrm{C} 13-\mathrm{C} 12 & 180.0(4)\end{array}$

$\begin{array}{ll}\mathrm{N} 21-\mathrm{C} 24-\mathrm{C} 25-\mathrm{C} 26 & -179.0(7) \\ \mathrm{C} 24-\mathrm{C} 25-\mathrm{C} 26-\mathrm{C} 21 & 0.0 \\ \mathrm{C} 22-\mathrm{C} 21-\mathrm{C} 26-\mathrm{C} 25 & 0.0 \\ \mathrm{C} 12-\mathrm{C} 21-\mathrm{C} 26-\mathrm{C} 25 & 179.9(7) \\ \mathrm{C} 24-\mathrm{N} 21-\mathrm{C} 27-\mathrm{C} 28 & -178.3(6) \\ \mathrm{N} 21-\mathrm{C} 27-\mathrm{C} 28-\mathrm{C} 29 & 2.2(11) \\ \mathrm{N} 21-\mathrm{C} 27-\mathrm{C} 28-\mathrm{C} 33 & -176.6(7) \\ \mathrm{C} 33-\mathrm{C} 28-\mathrm{C} 29-\mathrm{C} 30 & 0.0 \\ \mathrm{C} 27-\mathrm{C} 28-\mathrm{C} 29-\mathrm{C} 30 & -178.8(7) \\ \mathrm{C} 28-\mathrm{C} 29-\mathrm{C} 30-\mathrm{C} 31 & 0.0 \\ \mathrm{C} 29-\mathrm{C} 30-\mathrm{C} 31-\mathrm{C} 32 & 0.0 \\ \mathrm{C} 29-\mathrm{C} 30-\mathrm{C} 31-\mathrm{N} 22 & 178.0(8) \\ \mathrm{O} 21-\mathrm{N} 22-\mathrm{C} 31-\mathrm{C} 30 & -4.7(12) \\ \mathrm{O} 22-\mathrm{N} 22-\mathrm{C} 31-\mathrm{C} 30 & 170.1(13) \\ \mathrm{O} 21-\mathrm{N} 22-\mathrm{C} 31-\mathrm{C} 32 & 173.3(7) \\ \mathrm{O} 22-\mathrm{N} 22-\mathrm{C} 31-\mathrm{C} 32 & -11.8(15) \\ \mathrm{C} 30-\mathrm{C} 31-\mathrm{C} 32-\mathrm{C} 33 & 0.0 \\ \mathrm{~N} 22-\mathrm{C} 31-\mathrm{C} 32-\mathrm{C} 33 & -178.1(8) \\ \mathrm{C} 31-\mathrm{C} 32-\mathrm{C} 33-\mathrm{C} 28 & 0.0 \\ \mathrm{C} 29-\mathrm{C} 28-\mathrm{C} 33-\mathrm{C} 32 & 0.0 \\ \mathrm{C} 27-\mathrm{C} 28-\mathrm{C} 33-\mathrm{C} 32 & 178.7(7)\end{array}$

Hydrogen-bond geometry $\left(A,{ }^{\circ}\right)$

\begin{tabular}{lllll}
\hline$D-\mathrm{H} \cdots A$ & $D-\mathrm{H}$ & $\mathrm{H} \cdots A$ & $D \cdots A$ & $D-\mathrm{H} \cdots A$ \\
\hline $\mathrm{C} 5-\mathrm{H} 5 \cdots \mathrm{O} 2^{\mathrm{i}}$ & 0.95 & 2.55 & $3.489(7)$ & 172 \\
$\mathrm{C} 13-\mathrm{H} 13 \cdots \mathrm{O} 1^{\mathrm{ii}}$ & 0.95 & 2.57 & $3.426(5)$ & 151 \\
$\mathrm{C} 27-\mathrm{H} 27 \cdots \mathrm{Cl}^{\mathrm{i}}$ & 0.95 & 2.78 & $3.661(11)$ & 155 \\
\hline
\end{tabular}

Symmetry codes: (i) $x,-y+1 / 2, z-1 / 2$; (ii) $x+1,-y+1 / 2, z-1 / 2$. 